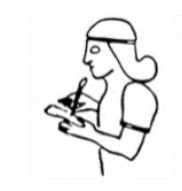

\begin{tabular}{|l|l|l|l|}
\hline ARCFIVUM ANATOLICUM (ArAn) & $15 / 2$ & 2021 & $357-383$ \\
\hline
\end{tabular}

\title{
CICERO'NUN PRO LIGARIO ADLI SÖYLEVINDE DEPRECATIO
}

\author{
Serap GÜR KALAYCIOĞULLARI*
}

\section{Makale Bilgisi}

Başvuru: 26 Temmuz 2021

Kabul: 12 Eylül 2021

Makale Türü: Araştırma Makales

\section{Article Info}

Received: July 26, 2021

Accepted: September 12, 2021

\section{$\ddot{O} z$}

Pro Ligario (Ligarius Savunmast), Caesar ile Pompeius arasindaki Iç Savaş sonrasında Cicero'nun forumda yaptı̆̆ ilk dava konuşmasıdır ve aynı zamanda Cicero'nun söylevleri arasinda bildiğimiz tek deprecatio (eylemin kasıt ile işlendiğinin itiraf edilmesi ve bağışlanma talep edilmesi) örneğidir.

Çalışmada öncelikle Ligarius'u yargıya götüren süreç ve dava hakkında genel bilgi verilecektir. Daha sonra Cicero'nun davada Ligarius'u savunmak için başvurduğu deprecatio, antik kaynaklar ışı̆̆ında tanımlanacaktır. Ardından savunma metni, kuramsal yapısı çerçevesinde deprecatio açısından incelenecektir. Nihayet Cicero'nun hangi ölçüde deprecatio'ya başvurduğu ve metnin tamamının bir deprecatio örneği olarak nitelenmesinin uygun olup olmadı̆̆ sorularına yanıt verilmeye çalışılacaktır.

Anahtar Kelimeler: Cicero, Ligarius, Caesar, deprecatio

Deprecatio in Cicero's Pro Ligario

Abstract

The Pro Ligario (Defense of Ligarius) is Cicero's first court speech at the forum after the Civil War between Caesar and Pompeius, and is also known as the only example of deprecatio (to confess the crime and premeditation, yet beg for pardon) among Cicero's orations.

In the study general information will be given about the case and the process that led Ligarius to trial. Later, the deprecatio Cicero applied to defend Ligarius in the case will be defined in the light of ancient sources.

* Dr. Öğr. Üyesi, Ankara Üniversitesi, Eskiçağ Dilleri ve Kültürleri, Latin Dili ve Edebiyatı, sgur@ankara.edu.tr, ORCID: 0000-0002-8184-9123 
Then, the speech Pro Ligario will be examined in terms of deprecatio within the framework of its theoretical structure. Finally, it will be tried to answer the questions to what extend Cicero applied deprecatio and whether the whole text can be qualified as a deprecatio.

Keywords: Cicero, Ligarius, Caesar, deprecatio

\section{Giriş}

Quintus Ligarius İÖ 50 yılında, Caesar ile Pompeius arasındaki İç Savaş başlamadan hemen önce, senato tarafindan Afrika eyaleti ${ }^{1}$ yöneticisi (propraetor) Gaius Considius Longus'un yanına legatus ${ }^{2}$ olarak atanır ve Afrika'ya gider. Aynı yılın sonunda Considius, Roma'daki consul seçimleri için Afrika'dan ayrilırken eyaletin sorumluluğunu Ligarius'a (legatus pro praetore) bırakır. Kısa bir süre sonra Caesar ile Pompeius arasındaki İç Savaş patlak verir (İÖ 49). Savaşta Caesar'ı destekleyenler Roma'da kalırken Pompeius'u destekleyenler onun peşinden İtalya'dan ayrilırlar. Bu sirada Afrika eyaletinde de Caesar karşıtı bir hareketlenme başlar ve buradaki halk bir önder arayışı içine girer. Ardından Pompeius yanlısı komutanlardan Attius Varus $^{3}$ Afrika'ya gelir. Varus, daha önceki y1llarda resmi olarak Afrika eyaleti yöneticiliği yaptığı için bölgeyi ve halkı iyi tanımaktadır, hem bu tanışıklıktan hem de yönetimdeki boşluktan faydalanarak eyalet üzerindeki yetkiyi (imperium) gayriresmi olarak ele geçirir. Bu sırada halen Afrika'da bulunan Ligarius da Varus'un otoritesini kabul eder ve hizmetine girerek bölgenin kıyı kesiminin kontrolünü üstlenir. ${ }^{4}$ Kısa süre sonra, senato tarafindan Considius'un ardılı olarak Afrika eyaleti yöneticiliğine atanan Lucius Aelius Tubero, ${ }^{5}$ yanında yolculuk sırasında hastalanan oğlu Quintus Tubero ile Afrika'ya görevini teslim almaya geldiğinde karaya çıkmasına izin verilmez. ${ }^{6}$

1 Afrika, Romalılar tarafından bölgede yapılan uzun ve yıpratıcı savaşların ardından İÖ 146 yılında eyalet haline getirilmiştir ve her yıl Roma'dan buraya yönetici gönderilmeye başlamıştır. Bk. App. Pun. 20.135.

2 Senato tarafından eyalet yöneticiliğine atanan kişi, eyalete yanında bir yardımcı ile giderdi. Legatus olarak adlandırılan bu kişi, senato tarafından, genellikle eyalet yöneticisinin verdiği isimler arasından seçilerek göreve atanırdı.

3 Publius Attius Varus, İç Savaş başladığında Caesar'a karşı, İtalya'nın doğu kıyısındaki Picenum'da büyük bir ordunun başında görev almıştır ancak Caesar'ın İtalya'da hemen hiç direnişle karşılaşmadan ilerlediği haberini alınca bulunduğu yeri terk etmiş ve önce Pompeius'un yanına Apulia'ya daha sonra da Afrika'ya geçmiştir. Bk. Caes. $B C$ 1.31.

4 Caes. BC 1.31; Cic. Lig. 22. Ayrica bk. Schol. Gronov. Pro Ligario, argumentum.

5 Quintilianus'un aktarımına göre Aelius Tubero, senato tarafından Afrika'ya tahıl tedariki için gönderilmiştir (inst. 11. 1. 80).

6 Cic. Lig. 27; Schol. Gronov. Pro Ligario, argumentum; Pomp. dig. 1.2.2.46. Caesar, Varus'un ve oğlunun karaya çıkmalarına izin verilmediğini aktarmıştır ancak bu noktada 
Bunun üzerine Lucius Aelius Tubero ve oğlu, Utica ${ }^{7}$ kıyılarından ayrılarak Makedonya'da Caesar'a karşı mücadele eden Pompeius'a katılırlar, Pompeius'un Pharsalus'taki yenilgisinin ardından ise Caesar tarafindan bağışlanırlar ve bu sayede Roma'ya geri dönerler. Ligarius ise İÖ 49 yılında Caesar'ın komutanlarından Curio'ya karşı yapılan Utica Savaşı sırasında ${ }^{8}$ ve İÖ 46 yılında bizzat Caesar'a karşı Numidia Kralı Juba ile ittifak ${ }^{9}$ halinde yapılan Thapsus Savaşı sırasında Varus'un hizmetinde Afrika'da kalmaya devam eder. ${ }^{10}$ Caesar'ın Thapsus'taki galibiyetinin ardından Hadrimentum'da yakalanır. Caesar onun yaşamını bağışlar fakat Roma'ya dönmesine müsaade etmez ve Ligarius bu andan itibaren sürgün duruma düşer. ${ }^{11}$ Ligarius'un Roma'daki iki erkek kardeşi bu haberi aldıktan sonra kardeşlerinin bağışlanması için çalışmalara başlarlar ve o sıralar sürgündeki Pompeius yanlılarının Roma'ya çağrılmaları için mücadele eden Cicero' ya ${ }^{12}$ başvururlar. $\mathrm{Bu}$ talebi kabul eden Cicero, 24 Eylül sabahı yanında Ligarius'un kardeşleriyle Caesar'ın evine gider. Buradaki görüşme sırasında iki kardeş yerlere kapanırken Cicero Caesar'dan Ligarius için af diler. Caesar onlara kesin bir yanıt vermez ancak Cicero görüşmenin hemen ardından Ligarius'a gönderdiği mektubunda (ad fam. 6.14), Caesar'ın tavırlarından umutlandığını, onun dönüşüne artık kesin gözüyle baktığını bildirir. Fakat tam bu sırada, Ligarius'un Afrika kıyılarını tuttuğu dönemde eyalete kabul edilmemiş olan Lucius Aelius Tubero'nun oğlu Quintus Tubero araya girer ve Caesar'ın huzuruna çıkarak Ligarius'un Afrika'da bulunmuş olmaktan yargılanmasını talep eder. Caesar tarafindan dava talebi kabul edilir.

Ligarius'tan bahsetmemiş, onların bölgenin kontrolünü ele geçiren Varus tarafindan engellendiklerini bildirmiştir ( $B C$ 1. 30-31).

7 Afrika Roma eyaleti yapıldıktan sonra Utica Afrika'nın başkenti olmuştur.

8 İÖ 49 yılının Ağustos ayında Varus, Caesar tarafindan Afrika'yı Pompeius yanlılarından temizlemesi ve bölgede sükûneti sağlaması için gönderilen Gaius Scribonius Curio ile karşı karşıya gelmiştir. Varus, Curio karşısında başarısız olmuştur. Bk. Caes. BC 2.33-34.

9 Numidia Kralı Juba, Caesar'ın komutanlarından Gaius Scribonius Curio'yu Afrika'da mağlup etmiştir. Bunun üzerine daha önce Curio karşısında başarısız olan Varus, Kral Juba'nın otoritesini kabul etmek ve Caesar'a karşı onunla ittifak kurmak durumunda kalmıștır. Bk. Caes. BC 2.36-44; Cass. Dio 41.42.

10 İÖ 46 yılının Nisan ayında Numidia ordularına önderlik eden Kral Juba ile Pompeius yanlıs1 ordulara önderlik eden Quintus Metellus Scipio, Afrika'nın Thapsus mevkiinde Caesar'la karşı karşıya gelmişlerdir. Bk. Plut. Caes. 53.1.

11 Caes. Bell. Afr. 89.

12 Cicero İç Savaşta Pompeius'un yanında yer almasına rağmen Caesar tarafından bağışlanmıştır ve Roma'ya döndükten sonra siyasi varlığını sürgündeki Pompeius yanlıları için mücadele ederek sürdürmüştür. Cicero'nun Caesar ile muhalifleri arasındaki tutumlarına ilişkin bk. William C. McDermott, "In Ligarianam”, TAPA 101 (1970): 320. 


\section{Dava}

İÖ 46 yılının Kasım ayında, ${ }^{13}$ halen sürgünde olan Ligarius'un davası Roma'da, forumda görülür. Caesar davada tek yargiç olarak bulunur. Bunun sebebi genellikle Caesar'ın bu sirada dictator olarak elinde bulundurduğu olağanüstü yetkiler ve Pharsalus Savaşının ardından kendisine tanınan, Pompeius yanlılanı hakkında dilediği eylemi gerçekleştirme hakkı ile açıklanmaktadır. ${ }^{14}$ Davada Tubero'nun suçlamalarına karşı Ligarius'u önce Caesar'ın yakın dostlarından Gaius Vibius Pansa ${ }^{15}$ daha sonra da Cicero savunur.

Ligarius'un resmi olarak hangi suç ve yasa kapsamında yargılanmış olduğu açık değildir fakat Cicero, savunmasında Ligarius'un "Afrika'da bulunmuş olmak" $a^{16}$ suçlandığını ifade etmiștir. Tek başına Afrika'da bulunmak suç teşkil etmeyeceğine göre en basit şekilde "Pompeius yanlısı olmak"17 şeklinde açıklanabilecek bu söylem, Ligarius'un Afrika'da bulunduğu sıradaki eylemleri ile ilişkilendirilmelidir: 1. Ligarius, Considius'un eyaletten ayrılmasıyla kendisinin de legatus olarak görevi sona erdiği halde Roma'ya dönmemiştir. 2. Varus Afrika'ya gelip Pompeius yanlılarının başına geçtiğinde onun otoritesini kabul etmiştir. 3. Senato tarafindan Afrika eyaleti yöneticiliğine atanan Lucius Aelius Tubero'nun, görevini teslim almak üzere karaya çıkmasına izin vermemiştir. 4. İhtiyaç halindeki bir Roma yurttaşının susuzluğunu gidermesine müsaade etmemiştir. 5. Caesar'ın komutanlarından Curio'ya karşı yapılan Utica Savaşı sırasında ve bizzat Caesar'a karşı yabancı bir kralla ittifak halinde yürütülen Thapsus Savaşı sırasında Afrika'da kalmaya devam etmiştir. Tüm bunlar Ligarius'un, özellikle de Thapsus Savaşı'nda kurulan söz konusu ittifaktan ötürü perduellio ya da maiestas kapsamında yargılanmış olabileceği sonucunu ortaya çıkarmaktadır. ${ }^{18}$

13 Shackleton Bailey, eski takvime göre eylül ayına denk gelen davanın yeni takvimdeki yerini kasım ayı olarak saptamıştır, bk. Cicero, Epistulae ad Familiares II (Cambridge, 2004), ad fam. 227 (6.13).

14 Cass. Dio 42.20.1.

15 Pansa'nın konuşmasına ilişkin bk. Kazimierz Kumaniecki, "Der Prozess des Ligarius", Hermes 95 (1967): 444-445; McDermott, 323.

16 "in Africa fuisse". Charles Edwars Ramos'a göre bu söylem, o dönem Caesar yanlılarının, Ligarius gibi Pharsalus Savaşı sonrası Caesar'a karşı savaşmaya devam eden Pompeiusçuları sınıflamak için kullandıkları aşağılayıcı bir slogan haline gelmişti ve bu kişiler Caesar'a Afrika'daki muhaliflerine karşı katı bir tutum sergilemesi konusunda baskı yapmaya çalışıyorlard1, bk. "Politics and Rhetoric: Studies in Cicero's Caesarian Speeches" (PhD diss., University of Texas, 1994), 175-176.

17 Afrika, İç Savaşın başlangıcından itibaren Caesar'a karşı Pompeius'u desteklemiştir.

18 Perduellio sözcügü, bir Roma yurttaşının kendi vatanına ya da vatanını yöneten kişiye düşmanlığını ifade etmekte idi. Yabancı bir düşmanla hareket ederek vatanına ihanet etme 
Cicero, Ligarius için yaptığı dava konuşmasında geleneksel savunma araçlarını bir yana bırakarak suçlamanın savunma tarafından kabul edildiğini bildirmiş ve müvekkili için Caesar'dan af talep etmiştir. Cicero'nun konuşmasından etkilenen Caesar dava sonunda Ligarius'un beraatine karar vermiştir. ${ }^{19}$ Davadan kısa bir süre sonra Cicero, savunma metnini üzerinde çok az değişiklik yaparak dostu Atticus'un katkısı ile yayımlamıştır. ${ }^{20}$ Günümüze ulaşan metin, Cicero'nun söylevleri arasında tek deprecatio örneği olarak değerlendirilmektedir. ${ }^{21}$

\section{Deprecatio:}

Latin yazınında hitabet üzerine yapılmış kuramsal çalışmalar arasında deprecatio'nun tanımına Cicero'ya ait de Inventione, Quintilianus'a ait Institutio Oratoria ve önceleri hatalı olarak Cicero'ya atfedilen bununla

eylemi, Cumhuriyetin erken dönemlerinde perduellio kapsamında yargılanmaktaydı. Bu tür fiiller aynı zamanda maiestas (açı hali ile crimen laesa maiestatis), yani vatanın yüceliğine zarar verebilecek fiiller kapsamındaydı. İÖ 81 yılında Lucius Cornelius Sulla, perduellio ile crimen laesa maiestatis'i birleştirerek lex Cornelia de maiestate' yi yapmıştır ve hangi fiillerin bu suç kapsamına girdiğine ilişkin şartları belirlemiştir. Ayrıntılı bilgi için bk. Rezzan İtişgen Dülger, "Vatana İhanet Suçunun Kökenleri Üzerine bir İnceleme", Marmara Üniversitesi Hukuk Fakültesi Hukuk Araştırmaları Dergisi 23/2 (2017): 104111; Kadir Gürten, “Roma'da Devlete Karşı İșlenen Bazı Suçlar ve Cezaları”, Ankara Barosu Dergisi 3 (2017): 56-62. Genel kanı Ligarius'un perduellio ile suçlandığı yönündedir. Bk. W. Y. Fausset, Cicero, Orationes Caesarianae, Pro Marcello, Pro Ligario, Pro Rege Deiotaro, Part II, Oxford (1893): 25; McDermott, 323; Walser, "Der Prozess gegen Q. Ligarius im Jahre 46 v.Chr", Historia 8 (1959): 92; Klaus Bringmann, "Der Dictator Caesar als Richter? Zu Ciceros Reden 'Pro Ligario' und 'Pro Deiotaro'," Hermes 141 (1986): 73-74; P. Christopher Craig, "The Central Argument of Cicero's Speech for Ligarius", The Classical Journal 79/3 (1984): 194; Holly W. Montague, “Advocacy and Politics: The Paradox of Cicero's Pro Ligario", AJPh 113/4 (1992): 561. Bauman'a göre, Ligarius, maiestas kapsamında suçlanmıştır. Bk. Richard Bauman, "A Study of the Crimen Maiestatis Imminutae in the Roman Republic and Augustan Principate" (PhD diss., University of the Witwatersrand, 1963), 142-149. Her iki yasa da Ligarius'un durumuna uygundur.

19 Plut. Cic. 39.5-6.

20 Ligarius Savunması'nın yayımlanma sürecine ilişkin bk. James Norwood Settle, "The Publication of Cicero's Orations" (PhD diss., University of North Carolina, 1962), 264268.

21 Ligarius'un davasındaki olağan dışı uygulamalar (Cicero'nun savunmasının deprecatio niteliğinde olması, savunmada suçlamaya ilişkin hukuki bir terim kullanılmaması, davanın tek bir yargıç tarafından görülmesi ve Ligarius'un, gıyabında yargılanması) bazı araştırmacılar tarafindan dava için gerekli işlemlerin yerine getirilmediği ve bunun Caesar'ın merhamet politikasına hizmet eden önceden planlanmış bir dava olabileceği şeklinde yorumlanmıştır. Bu konuda farklı görüşleri okumak için bk. Walser, 94-95. 
beraber yazarı kesin olarak bilinmeyen Rhetorica ad Herennium adlı eserlerde rastlamaktayız. ${ }^{22}$

Cicero, deprecatio'yu iuridicalis (eylemin haklı olup olmadığının tartış1lması) altındaki assumtiva (suçu kabullenme) yöntemlerinden biri olan concessio (af dileme) türleri içinde tanımlamıştır:

"Concessio, sanığın yaptığı eylemi savunmaması fakat bağışlanma talep etmesi durumudur. Bu iki kısma ayrılır: Purgatio ve deprecatio. Purgatio, eylemin kabul edilmesi, kabahatin ise başka şeye yüklenmesi durumudur. Bunun da üç şekli vardır: bilgisizlik, kaza ve zaruret. Deprecatio ise sanığın kasıt ile suç işlediğini itiraf etmesi bununla beraber bağışlanma talep etmesi durumudur, bu çok nadir başvurulabilen bir türdür (inv. 1.15)."

Cicero, deprecatio'nun mahkemeler için uygun olmadığını belirtmiştir ve bunun sebebi olarak da suçun kabul edilmesinin ardından suçları cezalandırmakla yükümlü kişilerden af beklemenin güç olmasını göstermiş̧tir (inv. 2.104). Ancak Cicero, bazı şartların mevcudiyetinde kısmen bu türe başvurulabileceğini açıklamıştır ve bu konuda sanığa ilişkin birtakım ilkeler üzerinde durmuştur:

"Dolayısıyla tüm savunmayı onun (deprecatio) üzerine inşa etmediğin sürece bundan kısmen yararlanman mümkün. Mesela savunduğun kişi devlete fazlaca iyiliği dokunmuş parlak ve yiğit bir şahıssa sanki deprecatio'ya başvurmuyor gibi yapıp şöyle diyebilirsin: 'Sayın Yargıçlar, eğer bu kişi yaptığı iyilikler adına, size her daim beslediği bağlılık adına böyle bir döneminde, doğru yaptığ 1 pek çok şeye karşıllık sizden tek bir yanlışını bağışlamanızı talep etseydi onun bu talebinin gerçekleşmesi sizin itibarınıza, onun ise yiğitliğine yaraşır bir durum olurdu.' Daha sonra sanığın yaptığı iyilikleri sayıp dökmek ve yargıçları beylik sözler aracılığıyla bağışlamaya yatkın hale getirmek uygun olacaktır.

Her ne kadar bu, mahkemelerde belli bazı kısımlar dışında kullanılmayan bir tür olsa da yine de hem bazen bu kısımların bilhassa eklenmesi gerektiğinden hem de senatoda veya mecliste s1k s1k her türe başvurmak icap ettiğinden buna

22 Cic. inv. 1.15, 2.94,104-109; Rhet. Her. 1.14.24, 2.17.25; Quint. inst. 5.13.5,31, 7.4.17-18. Deprecatio için ayrıca bk. Çağatay Aşkit, “Yargısal Söylev Türünde Cicero'nun Kuramlar ve Uygulamalart" (Doktora Tezi, Ankara Üniversitesi, 2006), 16-17. 
da ilkeler getirelim... Bağışlanma talep eden kişi, eğer yaptığı iyilikler varsa bunların hepsinden bahsetmeli ve mümkünse bunların yaptığı yanlışlardan daha büyük olduğunu göstermelidir ki onun kötülükten çok iyilik yaptığı anlaşılsın. Daha sonra eğer varsa atalarının iyiliklerini aktarmalı, ardından yaptığı şeyi nefretle ya da gaddarlıkla değil aptallıkla, birinin kışkırtmasıyla ya da onurlu veya kabul edilebilir bir sebeple yaptığını ispatlamalı, daha sonra yaptığı yanlıştan ders çıkardığını, kendisini bağışlayanların lütfu sayesinde gelecekte bu tür bir davranıştan katiyen uzak olacağını ifade ve taahhüt etmelidir. Sonrasında kendisinin onu affedenlere bundan sonra büyük yararı olacağı konusunda umut vaat etmelidir, ardından eğer mümkünse kendisinin onlarla (yargıçlar) akraba olduğunu ya da en eski atalarından beri dost olduğunu göstermelidir. Daha sonra iyi niyetinin büyüklügünü, soyunun asaletini, kendisinin esenliğini isteyenlerin itibarını öne sürmelidir. Sonra alçakgönüllülükle ve böbürlenmeden insanlara onur ve büyüklük için bahşedilen tüm diğer şeylerin kendisinde var olduğunu ifade etmelidir ki cezalandırılmaktan çok onurlandırılmaya layık olduğu anlaşılsın. Daha sonra çok daha ciddi suçlardan bağışlanan başkalarını saymalıdır. Şayet kendisinin elinde güç varken merhametli olduğunu ve bağışlamaya yatkın olduğunu gösterebilirse lehine olacaktır. Ayrıca işlenen suç, mümkün olduğunca az hasara yol açmış görünecek şekilde hafifletilmelidir ve böyle bir insanı cezalandırmanın çirkin veya faydasız olacağı ortaya koyulmalıdır. Ardından ilk kitapta açıklanan ilkeler uyarınca beylik sözler ${ }^{23}$ ederek merhamet duygusu uyandirmalıdır (inv. 2.104-108)."

Rhetorica ad Herennium'da da deprecatio, sanığın kasıt ile suç işlediğini itiraf etmesi ve bunu bilgisizlik (imprudentia), kaza (casus) ya da zaruret (necessitas) ile ilişkilendirmediği halde bağışlanma talep etmesi olarak açıklanmaktadır ${ }^{24}$ ve bunun mahkeme için uygun olmadığı görüşü desteklenmektedir:

"Deprecatio, sanığın hem suçu işlediğini hem de kasit ile işlediğini itiraf etmesi ve bu halde kendisine merhamet

\footnotetext{
23 loci communes: Yazgının insanoğlu üzerindeki gücünü ve bu güç karşısında insanoğlunun zayıflığını açığa vuran beylik deyişler, bk. Aşkit, 81.

24 Rhet. Her. 1.14.24, 2.17.25.
} 
edilmesini talep etmesi durumudur. Bunun mahkemede kullanılması pek mümkün değildir. Sadece eğer pek çok kez doğru davranmış bir kişiyi savunmaktaysak buna beylik bir söylemde abartma yoluyla başvurabiliriz: 'Gerçekten bunu yapmış olsa bile geçmişteki iyiliklerinden ötürü affedilmesi gerekirdi oysa hiçbir şekilde af talep etmiyor.' Bu tür bir savunma şekli mahkemeye uygun değil fakat senatoda, imperator'un huzurunda ve mecliste kullanilabilir (1.14.24)."

Rhetorica ad Herennium'da da mahkemede deprecatio'ya başvurmayı olanaklı hale getirecek ilkeler sanık, eylem ve toplum nezdinde sıralanmıştır:

"Sanığın hizmetlerinin yaptığı kötülüklerden daha büyük ve fazla olduğunun bilinmesi, af dileyen sanıkta belli bir erdem ve soyluluk bulunması, cezalandırılmadığ 1 takdirde gelecekte faydalı olacağı konusunda umut vaat etmesi, af dileyen kişinin kendi elinde güç varken yumuşak ve merhametli olduğunun ispatlanması, yaptığı şeyleri nefretle ya da gaddarlıkla değil bilakis görev duygusuyla ve doğru bir amaç uğruna yapmış olması, benzer bir davada başkalarının bağışlanmış olması, onu serbest bıraktığımız takdirde başımıza gelecekte ondan bir bela gelmeyeceğinin bilinmesi ve bu durumun bizim yurttaşlarımız ya da başka bir toplum nezdinde infial yaratmayacak olmas1 (2.17.25)."

Quintilianus da savunma araçlarını incelerken deprecatio'yu mahkemelere uygun olmayan ancak kısmen kullanılabilen bir tür olarak tanımlamıştır:

"Herhangi bir savunma mahiyetinde olmayan deprecatio, hakikatte nadiren ve sadece kesin bir hüküm verme biçimine tabi olmayan yargıçların huzurunda kullanılır. Bununla beraber Gaius Caesar'ın ve triumvir'lerin huzurunda muhalifler için yapılan savunmalar bile her ne kadar yakarışlara başvursalar da savunma araçlarını da içermektedirler, mesela şunu ancak şiddetli bir şekilde savunma yapan kişi söyleyebilir: 'Ey Tubero, biz şu kişinin (Caesar'ın) muktedir olduğu şeye bizzat muktedir olmayı istemekten başka ne amaç güttük?' Fakat eğer bir princeps veya karar verme yetkisi bulunan bir şahsin huzurunda savunma yaparken müvekkilimiz gerçekten ölüm cezasına layık olduğu halde ona merhamet edilmesi gerektiğini 
söylemek icap ederse her şeyden önce rakibe değil, yargıca odaklanmalıyız, sonra yargısal üsluptan ziyade müzakereci üslup kullanmalıyız. Yargıcı, intikam hazzından çok insanc1lıkla kazanılan övgüyü arzulamaya teşvik etmeliyiz (inst. 5.13.5-6)."

Quintilianus, deprecatio'nun mahkemelerde başvurulacak son şey olduğunu fakat savunmanın tümünde değilse de sıklıkla bazı kısımlarında kullanıldığını aktarmıştır ve bu türe başvurmak için gerekli ilkeleri, Cicero'nun verdiği ilkeler ile örtüşecek şekilde belirlemiştir:

"Sonuncusu deprecatio'dur ancak bugüne dek çoğu kişi bu türün mahkemeye uygun olduğunu reddetmiştir. Görünen o ki Cicero da Ligarius savunmasında şu ve benzeri sözlerle aynı şeyi savunur: 'Ey Caesar, itibar basamakları seni forumda tutarken ben şahsen seninle pek çok davaya katıldım. Şüphesiz hiç şu tarz bir şey duymadık: Bağışlayın, Sayın Yargıçlar, hata etti, yanıld1, düşünmeden yaptı, bir daha m1, asla.' Ancak senatoda, halkın ve princeps' in huzurunda ve merhamet etme yetkisi bulunan birinin olduğu her yerde deprecatio'nun yeri vardır. Burada sanığa ilişkin özellikle geçerliliği olan üç şey bulunur: 1. Zararsız ve faydalı biri olarak sürdügü geçmiş yaşamı. 2. Gelecekte zararsız bir hayat yaşam süreceğine ve herhangi bir konuda yararlı olacağına ilişkin verdiği umut. 3 . Gerek başka talihsizlikler gerek mevcut bir tehlike gerek pişmanlık yüzünden cezasını fazlasıyla ödemiş olduğuna inanılması. Ek olarak soyluluğu, itibarı, yakınları, dostları. Bununla beraber özellikle soruşturmayı yapan kişiye umut bağlanmalıdır, yıkmanın getireceği ayıplamadan çok merhametin kazandıracağı övgüye odaklanılmalıdır. Aslında bu yol mahkemelerde savunmanın tamamında değil ama büyük bir kısmında sıkça kullanılır. Mesela bölümleme kısmında şu şekilde çok kullanılır: 'Sanık bu eylemi yapmış olsa bile bağışlanmayı hak etmiştir.' Bunun genellikle şüpheli davalarda geçerliliği olmuştur ve genellikle tüm sonsözler hemen hemen aynı araçları içerir (inst. 7.4.17-19)."

Cicero'da, Quintilianus'ta ve Rhetorica ad Herennium'da yer alan tüm bu tanım ve açıklamalar uyarınca deprecatio'ya ilişkin özetle şunlar söylenebilir: 
1. Tanım:

Deprecatio, sanık tarafindan eylemin kasıt ile işlendiğinin kabul edilmesi ve bu halde bağışlanma talep edilmesidir.

2. Kullanıldığı yerler:

- Mahkemelerde kısmen ve nadiren,

- Senatoda,

- Mecliste,

- Halkin huzurunda,

- Imperator'un huzurunda,

- Triumvir'lerin huzurunda,

- Princeps'in huzurunda,

- Merhamet gösterme yetkisi bulunan birinin olduğu her yerde

3. Mahkemede sanığın deprecatio için uygunluğu:

- İtibar, asalet ve erdem sahibi olmas1,

- Saygın dostları ve yakınlarının bulunması,

- Geçmişte vatanına kötülükten çok iyiliğinin dokunmuş olması,

- Yaptığı eylemi nefretle ya da gaddarlıkla değil görev ya da doğru bir amaç için yapmış olması,

- Güç sahibi iken merhametli ve yumuşak davranmış olmas1,

- Yaptığ 1 eylemden ötürü yeterince ceza çekmiş görünmesi,

- Gelecekte devlete zararının dokunmayacağı bilakis faydalı olacağı konusunda umut vaat etmesi,

- Bağışlanmasının toplumda herhangi bir infiale yol açmayacak olması.

4. İzlenecek yol:

- Sanığın yaptığı iyilikler sayılır, mümkünse bunların yaptığ 1 kötülüklerden fazla olduğu ortaya konulur,

- Atalarının devlete olan hizmetleri aktarılır,

- Yaptığ 1 eylemi, nefretle ya da zalimlikle değil, aptallıkla ya da birinin kışkırtmasıyla ya da dürüst veya kabul edilebilir bir gerekçeyle yaptığı ispatlanır,

- Sanığın yaptığı eylemden ders çıkardığı ve gelecekte bu tür davranışlardan kaçınacağı ifade edilir,

- Gelecekte onu affedenlere faydalı olacağı gösterilir,

- Sanığın ve atalarının yargıçlarla olan dostane ilişkilerinden bahsedilir, 
- Sanığın iyi niyetinin büyüklüğü, soyunun asaleti ve sanığın iyiliğini isteyenlerin itibarı öne sürülür,

- Denk ya da daha ciddi suçlardan bağışlanmış başka isimler emsal gösterilir,

- Sanığın güç sahibi iken merhametli olduğu ifade edilir,

- Eylem mümkün olduğunca az hasara yol açmış görünecek şekilde hafifletilir,

- Sanığı cezalandırmanın faydasız ve çirkin olacağı gösterilir,

- Yargıç, sanığı bağışladığı takdirde kazanacağı övgüyü elde etmeye teşvik edilir,

- Beylik sözlerle yargıçta şefkat duyguları uyandırılır.

\section{Pro Ligario'da Deprecatio:}

Quintilianus, Cicero'nun Pro Ligario söylevini savunma araçlarının (patrocinia) da kullanıldığ 1 bir deprecatio örneği olarak değerlendirmiştir (inst. 5.13.5). Yaygın olarak kabul gören bu değerlendirmeye göre söylev, Cicero'nun konuşmaları arasında elimizde bulunan tek deprecatio örneğidir. ${ }^{25}$ Hangi noktalarda ve hangi sıklıkla deprecatio'nun kullanıldığını görebilmek için savunmanın kuramsal yapısına paralel bir inceleme yapmak uygun olacaktır:

Exordium (Giriş, Lig. 1-2) ${ }^{26}$

Savunmaya ilişkin ana başlıkların sunulduğu giriş bölümünde Cicero, müvekkiline yöneltilen suçlamanın ne olduğunu ("in Africa fuisse") açıklamıştır. Caesar'ın samimi dostlarından Pansa tarafından suçlamanın kabul edildiğini dolayısıyla bu konuda tartışmaya yer kalmadığını ifade etmiş ve doğrudan Caesar'a hitap ederek savunmasında kullanacağı yöntemi şu sözlerle belirtmiştir:

25 G. M. Long, Tulli Ciceronis Orationes, Vol. 4 (London, 1858), 401; Fausset, II.24; Walser, 90; McDermott, 318; Bringmann, 77. Öte yandan bu konuda kesin bir fikir birliği bulunmamaktadır. Cicero'nun metinde savunma araçlarını da yer yer kullanması, bu konu üzerine etraflıca çalışan Craig tarafından metnin kasıt yönünden savunma yapmaya olanak tanıyan purgatio ile harmanlanmış olduğu şeklinde yorumlanmıştır (196). Montague (561562) onunla aynı fikirdedir. Ramos'un araștırmasına göre (193-256) metinde deprecatio sadece kısmen, bazı noktalarda bir araç olarak kullanılmıştır; Ramos, tüm metni deprecatio olarak değerlendirmenin yanlış olduğunu ileri sürmüştür.

26 Exordium için bk. Cic. inv. 1.20; Rhet. Her. 1.6. Ayrıca bk. Aşkit, 33-42. 
"Kanıtları bir yana bırakıp konuşmamda tamamen senin bağışlayıcılığına hitap etmem gerekiyor. Nitekim senden, kabahatinin aklanması için değil hatasının bağışlanması için medet ummuş pek çok kişi bu sayede kurtulmuştur. Demek sen, Tubero, bir davacı için en çok arzu edilecek şeye sahipsin: Suçunu kabul eden bir sanı̆ga fakat aynı zamanda kendisinin, seninle ve de senin her anlamda saygıdeğer babanla aynı tarafta bulunduğunu kabul eden bir sanığa. Dolayısıyla Ligarius'u herhangi bir suçlamayla yargılamadan önce kendi kabahatinizi kabul etmek zorundasinız. (Lig. 1-2)"

Cicero bu şekilde sanık tarafından eylemin kasıt ile ${ }^{27}$ işlendiğini kabul etmiş ve konuşmasının tamamının (omnis oratio) ${ }^{28}$ yargıcın bağışlayıcılığına (ad misericordiam tuam) hitap edeceğini bildirmiştir. Daha önce yaptıkları hatadan ötürü af dileyip bağışlanan kişileri emsal göstermiştir. Cicero'nun kastettiği kişiler Caesar'a karşı savaşan Pompeius yanlılarıdır. Nitekim Caesar, Cumhuriyet kurumlarını yeniden bir düzene sokmak ve kendi konumunun meşruiyetini sağlamak için aralarında Cicero'nun ve davacı Tubero'nun da bulunduğu pek çok muhalifini bağışlamak durumunda kalmıştır. ${ }^{29}$

Yapılan eylemin sanı tarafindan kabul edilmesi, bu konuda savunma makamından Pansa'nın Caesar ile samimiyetine atıfta bulunulması, aynı eylemde bulunduğu halde bağışlanmış kişilerin emsal gösterilmesi, eylemin bir hata (erratum) şeklinde ifade edilerek hafifletilmesi ve bu bağlamda Caesar'ın bağışlayıcılığının dile getirilmesi deprecatio'ya uygundur.

27 Cicero suçlamayı "Afrika'da bulunmuş olmak” şeklinde açıklamıştır. Sonrasında verdiği bilgiler, Afrika'da bulunmanın nihayetinde müvekkilinin kendi kararı olduğunu göstermektedir.

28 Ramos (206-209) “omnis" sıfatında ironi bulunduğunu iddia etmiştir. Ona göre Cicero bu sözcüğü kullanarak Caesar'ın ve dinleyicilerden retorik konusunda bilgili olanların anlayabileceği şekilde Ligarius'u geleneksel savunma araçlarından faydalanarak savunacağını ve merhamet için yakarışlara başvurmayacağını ima etmiştir. Kanımca omnis sıfatında ironi bulunmamaktadır nitekim Cicero konuşmasının her bölümünde Caesar'ın merhametine hitap etmiştir, savunma araçlarının ise metne dolaylı bir katkısı bulunmaktadır.

29 Caesar'ın clementia politikası hakkında bk. Aaron Rozeboom, "The Rhetorical Implications of Clementia in Cicero's Caesarian Speeches", McNair Scholars Journal 11/1 (2007). 
Narratio (Anlatım, Lig. 2-4) $)^{30}$

Olayların nasıl geliştiği konusunda kısa ve açık bir bilgilendirmenin yapıldığı narratio bölümünde Cicero, Ligarius'un neden Afrika'ya gittiğini ve eyalet yöneticisi Considius Afrika'dan ayrıldıktan sonra neden orada kalmaya devam ettiğini açıklamıştır. Bu noktada müvekkilini hizmet ettiği kişilerin takdirini ve sevgisini kazanan, barış yanlısı bir karakter olarak tasvir etmiştir:

"Quintus Ligarius, Afrika'ya hiçbir savaş belirtisinin olmadığı bir dönemde Gaius Considius'un yanında legatus olarak gitti. $\mathrm{Bu}$ görevde iken hem yurttaşlara hem müttefiklere kendisini öyle beğendirdi ki şayet Considius ayrilırken eyaletin kontrolünü başka birine bıraksaydı insanları katiyen memnun edemezdi. Bundan ötürü Ligarius uzun süre karşı çıkmasına rağmen başarılı olamayınca eyaleti gönülsüzce kabul etti. Ancak barış zamanı öyle bir yöneticilik yaptı ki doğruluğu ve dürüstlüğü ile hem yurttaşlardan hem müttefiklerden büyük beğeni ve takdir topladı. Savaş aniden patlak verdi. Öyle ki Afrika'da bulunanlar, savaş hazırlıklarını dahi duymadan savaşın başladığı haberini aldılar. Bu haberi aldıktan sonra kısmen bilinçsiz bir arzu kısmen kör bir korku ile önce güvenliklerini sonra ilkelerini gözetecek bir önder aramaya koyuldular. $\mathrm{Bu}$ sırada evinin yolunu gözleyen, ailesine dönmek isteyen Ligarius ise kendisini mesuliyet altına sokacak herhangi bir adım atmadı. Derken daha önce propraetor olarak Afrika'yı yönetmiş olan Publius Attius Varus Utica'ya geldi. Etrafinda hemen bir kalabalık toplandi. Böylece bu şahıs kayda değer bir coşku ile yetkiyi ele geçirdi. Tabi hiçbir resmi karar olmaksızın bilgisiz kalabalığın hususi tezahüratı ile verilmiş bir şeye yetki denebilirse... Dolayısıyla bu anlamda her tür mesuliyetten kaçınmak isteyen Ligarius, Varus'un gelişiyle biraz olsun rahatladı. Ey Gaius Caesar, bu noktaya kadar Q. Ligarius'ta herhangi bir kabahat bulunmamaktadır (Lig. 2-4)."

$\mathrm{Bu}$ bölümde sanığın Afrika'da kalışının görev (officium) ile ilişkilendirilmesi, savaş başlamadan önceki yaşamında vatani görevini layıkıyla yerine getiren ve herkesi memnun edecek şekilde hareket eden bir yurttaş olarak sunulması, bunun yanında elinde firsat varken kendisini

30 Narratio için bk. Cic. inv. 1.28-29; Rhet. Her. 1.4, 14-16; Quint. inst. 4.2.31. Ayrıca bk. Aşkit, 42-45. 
mesuliyet altına sokacak herhangi bir adım atmamış ve Varus'un gelişi ile rahatlamış olmasının vurgulanması deprecatio'ya uygundur. Nitekim bunlardan sonuncusu, ayn1 zamanda Ligarius'un, Pompeius adına savaşmakta olan Varus'un otoritesini isteyerek kabul ettiği anlamına gelmektedir. Cicero, Ligarius'un İç Savaşıı başlamasından Varus'un gelişine dek geçen süreç içerisinde neden Afrika'da kalmaya devam ettiği ve onun otoritesini kabul ettiği sorularını göz ardı etmiştir.

Partitio (Bölümleme, Lig. 4-5) ${ }^{31}$

Konuşmada üzerinde durulacak noktaların kısa ve öz olarak ifade edildiği partitio bölümünde Cicero, davacının "Ligarius Afrika'da idi." şeklindeki söylemine karşı suçlamanın tartışmaya açık kısımlarını belirleyecek şekilde dönemsel bir bölümleme yapmıştır: 1. Ligarius'un Afrika'ya gittiği dönem, 2. Afrika'da kaldığı dönem, 3. Varus'un gelişinden sonra Afrika'da kalmaya devam ettiği dönem. Cicero, ilk döneme ilişkin, kötü niyet taşımayan bir maksada (voluntatem ... non turpem), ikinci döneme ilişkin ise onursal bir zarurete (necessitatem ... honestam) işaret etmiştir ve bunları herhangi bir suç unsuru (crimen) barındırmadıkları gerekçesiyle kenara ayırmıştır. Varus'un gelişinden sonra Ligarius'un Afrika'da kalmaya devam ettiği üçüncü dönem ise tartı̧̧maya açık olan kısımdır. Cicero bu döneme ilişkin olarak zaruret halinde işlenmiş bir suç (necessitatis crimen, non vontuntatis) bulunduğunu kabul etmiştir:

"Şayet bu kısımda bir suç unsuru varsa bu kasten değil zaruret halinde işlenmiş bir suçtur. Zira herhangi bir şekilde çıkıp gitme imkânı olsaydı müvekkilim Utica'da mı yoksa Roma'da m1, Publius Attius Varus'un mu yoksa biricik kardeşlerinin yanında mi, yabancilarla mı yoksa kendi dostlarıla mı olmayı tercih ederdi? Legatus'luğu dahi kardeşlerine olan inanılmaz sevgisi yüzünden hasret ve gam dolu geçmişken bu kez savaşın bölücülügü yüzünden kardeşlerinden koparıldığında orada aynı sükûnet ile kalmaya devam etmesi mümkün olmuş olabilir mi? (Lig. 5)"

Cicero'nun, Ligarius'un Afrika'da kalmaktan başka bir seçeneği bulunmadığını ima ettiği bu kısım, kasıt (voluntas) yönünden savunma yapmaya olanak tanıan purgatio niteliğindedir. Öte yandan Cicero, buradaki zarureti doğrudan Ligarius'un şahsına değil süreç üzerine yüklemiştir. Ligarius'u Afrika'da tutan zorunlu sürecin dayanağı olarak

31 Partitio için bk. Cic. inv. 1.31-33; Quint. inst. 3.9.1, 4.5; Rhet. Her. 1.4.17. Ayrıca bk. Aşkit, 45-47. 
aniden patlak veren savaşı göstermiştir. Savaş, Ligarius'un Afrika'da kalmaya devam etmek zorunda kalmasının altındaki "kabul edilebilir sebep"tir. Bu kısım ayrıca diğer Pompeius yanlıları ile kıyaslandığında Ligarius'un daha hafif bir eylemde bulunmuş olduğuna işaret etmesi bakımından bir sonraki tartışma bölümünü temellendirmekte ve bu bağlamda deprecatio'ya hizmet etmektedir.

Argumentatio (confirmatio et reprehensio: Kanıtlama ve Çürütme, Lig. 6-28) ${ }^{32}$

Kuramsal olarak davaya ilişkin kanıtların ortaya koyulduğu ve iddiaların çürütüldüğü bu bölümde Cicero, suçlamanın hedefini geldiği yöne çevirmek şeklinde bir yol izlemiştir. Bu doğrultuda sırayla kendisinin, Tubero'nun ve Caesar'ın İç Savaşa ilişkin tutumlarını irdelemiştir. Ardından ilk kez Tubero'nun iddialarına yanıt niteliği taşıyacak ifadelerde bulunmuștur. Bu bölüm bütün olarak bir nevi Tubero'ya saldırı (vituperatio Tuberonis $)^{33}$ niteliğindedir.

Öncelikle Ligarius'un buraya kadar Caesar'a aykırı bir oluşum içinde yer aldığına dair herhangi bir kanıt bulunmadığını belirten Cicero, bu oluşumda bizzat yer almış biri olarak şahsını emsal göstermiştir. Nitekim Cicero kendisi de İ ç Savaş sırasında Pompeius'u desteklemiş, onun ardından gitmiştir, Pompeius'un başarısız olacağını anladığında ise savaştan çekilmiş ve daha sonra Caesar'ın affı sayesinde Roma'ya geri dönebilmiştir. ${ }^{34}$ Cicero, şahsını öne sürerek kendisini affetmekle kalmayıp aynı zamanda itibarını da iade eden Caesar'ın merhametini (clementia) yüceltmiştir:

"Ah bu ne yüce bir merhamet! Eserlerde ve abidelerde tüm insanların övgüsü ve takdiri ile kutlanması gerek! Marcus Cicero, burada, senin huzurunda şahsen dahil olduğunu kabul ettiği bir oluşuma bir başka kişinin dahil olmadığını savunuyor! Üstelik ne senin dile gelmemiş düşüncelerinden korkuyor ne de senin o kişi hakkında söylenenleri dinlerken seninle karşı karşıya kalmaktan çekiniyor. Ne kadar rahat olduğuma bak, bak, senin hoşgörünün ve bilgeliğinin saçtığ ne güçlü bir 1şık, senin huzurunda konuştukça ben üzerimde yükseliyor. Sesimi var gücümle yükselteceğim ki Roma halk1

32 Confirmatio et reprehensio için bk. Aşkit, 47-74.

33 James M. May, Trials of Character: The Eloquence of Ciceronian Ethos (The University of North Carolina Press, 1988), 142-144.

34 Plut. Cic. 39. Cicero'nun Pharsalus Savaşı öncesi ve sonrası tutumlarına ilişkin bk. Brandtly Neal Jones, "Caesar: Slain with Daggers but Stabbed with Words" or "Cicero as a Failure and Fraud" (Chancellor's Honors Program Projects, 1998), 1-12. 
şunu iyice duysun: Ey Caesar, savaş başlamışken ve hatta savaşın büyük bölümü geride kalmışken hiçbir zorlama olmaksızın kendi hür irade ve isteğimle sana karşı tutulan saflara kat1lmaya gittim (Lig. 6-7)!"

Cicero'nun, Ligarius'un değil ama kendisinin dahil olduğu oluşum için kullandığı sözcük "voluntas”tır, Cicero bu sözcüğü kullanarak Pompeius'u gönülden destekleyen şahsı ile Ligarius arasında niyet yönünden bir ayrım yapmıştır.

Cicero'nun bu bakımından Ligarius'tan ayırdığı bir diğer kişi ise davacı Tubero'dur. Nitekim Tubero da İç Savaş sırasında babası ile Afrika'ya gitmiş, eyalete kabul edilmeyince Pompeius'a katılmak üzere Makedonya'ya ilerlemiş, Pharsalus Savaşında Caesar'a karşı mücadele etmişti ve Pompeius'un mağlubiyetinin ardından Roma'ya Caesar'ın affı sayesinde dönebilmişti. Cicero İç Savaşa ilişkin doğrudan Tubero'ya sorduğu sorularla onu adeta köşeye sıkıştırmıştır, onu davacı olarak bulunduğu mahkemede yargıçla karşı karşıya getirmiştir:

"Afrika'da bulunmuş olmanın suç olduğunu düşünen kim? Elbette şu kişi: Aynı eyalette bulunmayı asıl kendisi arzu etmiş olan ve şimdi de Ligarius tarafindan engellendiği gerekçesiyle yakınan, hiç şüphesiz silahlı biçimde Caesar'a karşı bizzat saf tutmuş olan kişi. Ey Tubero, senin o kınından çıkmış kılıcın Pharsalus cephesinde ne yapıyordu? O keskin ağız kimin ciğerine doğrulmuştu? Kuşandığın silahların amacı ne idi? Zihnin nerede idi? Gözlerin? Ellerin? Ruhundaki ateş? $\mathrm{Ne}$ istiyordun? Ne arzuluyordun? Fazla zorluyorum, genç adam sarsılmış görünüyor; kendime döneyim: Ben de aynı cephedeydim! (Lig. 9)"

Cicero'nun konuşmasının devamı, müvekkili adına bir savunmadan çok davacı Tubero'ya karşı bir itham niteliğindedir. Cicero, bu noktada Tubero'ya etik yönden derecesi artan altı suç atfetmiştir:

1. "Yaptığı eylemi kabul eden birine suçlamada bulunuyorsun! (Lig. 10)"

2. "Dahası var; ya benim dediğim gibi senden daha iyi ya da senin kabul ettiğin gibi seninle eş dayanağı olan bir kişiyi suçluyorsun! (Lig. 10)"

3. "Bunlar akıl almaz şeyler fakat asıl şimdi söyleyeceğim şey hakikaten korkunç: $\mathrm{Bu}$ suçlama, Q. Ligarius'un mahkumiyetini değil ölümünü hedefleyen bir niteliğe sahip! (Lig. 11)" 
4. "Eğer bu kişi sürgünde ise, ki öyle, siz daha ne talep ediyorsunuz? Yoksa bağışlanmamasını mı? Fakat bu çok daha sert ve insafsizca! (Lig. 13)"

5. "Sen buna suç mu diyorsun, Tubero? Niçin? Zira şu güne dek bu mesele için böyle bir adlandırma yapılmamıştır. (Lig. 17)"

6. "Eğer birinin bir şeyi arzu etmiş olması kabahatse sizin tüm eyaletlerin adeta kalesi olan ve kentimize karş1 savaşmak için var olan Afrika'ya sahip olmayı arzu etmiş olmanız, bir başka kişinin buna kendisini yeğ tutmuş olmasından daha önemsiz değildir. (Lig. 22)"

Cicero'nun Tubero'yu savunmanın hedef noktası durumuna getirdiği ithamlardan ilki sanığa ilişkindir; Ligarius'un zaten suçunu kabul etmiş olmasına işaret etmektedir. Ligarius'un akrabaları ve Cicero, dava öncesinde onun bağışlanması için Caesar'la görüşmüşlerdir, Tubero ise bunu bildiği halde onu dava etmiştir.

İkincisi eylemin dayanağına (causa) ilişkindir; İç Savaş sırasında Afrika'da bulunan Ligarius'un (Cicero'nun bakış açısına göre) Tubero'dan daha iyi ya da (Tubero'nun bakış açısına göre) en az onunki kadar iyi bir dayanağa sahip olduğuna işaret etmektedir. Cicero'nun burada her iki ihtimali de göz önünde bulundurması, sanığın -tıpkı Tubero gibi- eylemi kasit ile işlemiş olabileceği seçeneğinin bulunduğunu ve Tubero'nun iddiasının bu yönde olduğunu göstermektedir. Cicero suçlamanın baştan kabul edildiğini bildirerek bu seçeneği tasdik etmiştir. Cicero'nun varmak istediği nokta şudur: Afrika'da bulunmuş olma konusunda en başta oraya bir görev için giden Ligarius'un, oraya savaş sırasında giden ${ }^{35}$ ve karaya ayak basmasına izin verilmeyince soluğu Pompeius'un yanında alan Tubero'dan daha iyi ya da en az onun kadar iyi bir gerekçesi vardır dolayısıyla Tubero affedildiğine göre aynı şeyi Ligarius'un da talep ve elde etme hakkı bulunmaktadır.

Cicero'nun Tubero'ya yaptığı üçüncü itham ise suçlamanın yaptırımına ilişkindir. Cicero'ya göre müvekkili zaten sürgünde olduğuna göre mahkûm edilmesi durumunda geriye kalan tek seçenek ölümdür. Cicero Tubero'nun bu konudaki tutumunu, daha önce hiçbir Roma yurttaşının kalkışmadığı, kan dökmeye susamış barbarlara özgü bir davranış olarak

35 Tubero'nun babası her ne kadar senato tarafindan atandığ için Afrika'ya gitmiş olsa da Cicero onun niyetini sorgulamaktadır: "Öyle veya böyle, sizin şu şikâyetiniz ne anlama geliyor: 'Eyalete kabul edilmedik.' Edilseydiniz ne olacaktı? Onu Caesar'a teslim mi edecektiniz yoksa Caesar'a karşı tutacak mıdınız? (Lig. 23)" 
nitelemiştir ve Tubero'nun gaddarlıkta dictator Sulla'y1 ${ }^{36}$ bile aştığını ima etmiştir:

“Oysa nefret ettiği herkesi ölüme çarptıran o dictator'un zamanında dahi kimse böyle bir şeye kalkışmamıştır. O, kimseden talep gelmeden kendisi ölüm emri veriyordu, ödüllerle de teşvik ediyordu. Onun bu zulmünün hesabı ancak y1llar sonra senin şimdi burada zulüm beklediğin kişi tarafindan sorulmuştur. ${ }^{37}$ ( Lig. 12)"

Cicero daha sonra Tubero ile olan yakınlığını öne sürerek üslubunu bir nebze yumuşatmıştır ve onun aslı amacının bu olmadığına emin olduğunu ancak vaziyetin bu şekilde göründüğünü ifade etmiştir ( Lig. 1213). Bununla beraber Cicero, kırk yıl kadar önce Sulla ile Roma'ya yerleșen korku ortamını akıllara getirerek ve onun tutumları ile önce Tubero'nun daha sonra da Caesar'ın tutumları arasında kıyas yaparak Caesar'ın benimsediği merhamet politikasını taçlandırmıştır.

Cicero'nun Tubero'ya yaptığı dördüncü itham ise onun Ligarius'a karşı davranışının başkalarını da etkileyecek genel sonuçlarına ilişkindir. Cicero, Tubero'nun insafsızlığını daha da belirgin hale getirmek için dava öncesi Caesar'ın evinde gerçekleşen görüşmeye atıfta bulunmuş ve oradaki sahneye Tubero'yu yerleştirerek hayali olarak konuşturmuştur ve bunu yaparken onu bu kez sadece Ligarius'la değil af bekleyen diğer tüm Pompeius yanlılarıyla karşı karşıya getirmiştir:

"Eğer biz, evde yaptığımız -ve umuyorum boşuna yapmadığımız- bu şeyi yaparken sen aniden içeri dalsaydın ve şöyle bağırmaya başlasaydın: 'Ey Gaius Caesar, sakın bağışlama, sana kardeşlerinin esenliği için yakaran bu kişilere sakın acıma!' Böyle yaparak tüm insanlığını fırlatıp atmış olmaz miydın? İşte bizim evde talep ettiğimiz şeye senin forumda savaş açman ve böyle perişan durumda olan pek çok kişi için ${ }^{38}$ af yolunu kapatman bundan bile daha insafsızca. Ey

36 Lucius Cornelius Sulla. İÖ 82-79 yıllarında Roma dictator'u. Sulla, halk sınıfı tarafindan desteklenen Gaius Marius yanlılarına karşı verdiği mücadelede galip gelmesinin ardından kendisini dictator ilan ettirmiştir (İÖ 82) ve kendi isteği ile görevden çekildiği İÖ 79 yılına kadar çeşitli kanun ve reformlarla senatoyu Roma siyasetinde etkin bir konuma getirmek için mücadele etmiştir. Bu süreçte Marius'un tarafında yer almış herkesi düşman saymıştır. Sulla'nın emri ile bu kişilerin isimleri listelenerek meydanlara asılmıştır ve başlarına ödül koyulmuştur. Sulla'nın kara liste (proscriptio) uygulamaları hakkında bk. Plut. Sull. 31.

37 Plutarkhos, Caesar'ın dictator ilan edildikten sonra Sulla döneminde mahkûm edilen şahısların çocuklarına yurttaşlık haklarını geri verdiğini aktarmıştır (Caes. 37.1).

38 Halen sürgünde olan diğer Pompeius yanlıları kastedilmektedir. 
Caesar, düşündüğüm şeyi açıç̧a söyleyeceğim. Şayet sahip olduğun bu yüce talihte sen kendi içinde, tekrar söylüyorum, kendi içinde böylesi büyük bir hoşgörürlük taşımasaydın -ne dediğimin farkındayım- şu zafer feci bir yas ile dolardı. Yenilenler arasında dahi senden acımasızlık bekleyenler olduğuna göre yenenler arasında senden bunu isteyecek ne çok kişi olurdu! Bizzat affettiğin şu kişiler dahi senin başkalarına karşı affedici olmanı istemediklerine göre senin kimseyi bağışlamamanı arzulayarak merhamet göstermeni engelleyecek ne çok kişi olurdu! (Lig. 14-15)"

Cicero, dolayısıyla sözlerini bir kez daha Caesar'ın hoşgörüsünü ve merhametini vurgulayarak bitirmiştir.

Cicero'nun Tubero'ya yaptığı beşinci itham ise dava talebinin içeriğine ilişkindir. $\mathrm{Bu}$ noktada doğrudan Caesar'a ve zaferine ilişkin meselelere temas eden Cicero, Tubero'nun dava talebinde yer alan "scelus" sözcügünün Ligarius'un işlediği eyleme uygunluğunu tartışmış ve bu yolla İç Savaşa ve Caesar'ın zaferine ilişkin kendi düşüncelerini aktarmıştır:

"Sen buna suç mu diyorsun, Tubero? Niçin? Zira şu güne dek bu mesele için böyle bir adlandırma yapılmamıştır. Kimileri hata kimileri korku diyor; daha katı olanlar beklenti, ihtiras, nefret ya da inat diyor; çok daha katı olanlar ise küstahlık diyor. Şu güne dek senden başka kimse suç dememiştir. Başımıza gelen bu illet için ille de uygun ve doğru bir ad bulmak gerekirse bence olan şu: Kaderden kaynaklanan bir felaket meydana geldi ve insanların zihinlerini hazırlıksızken esir aldı. Kaldı ki kimse insani iradenin tanrısal istenç karşısında yenik düşmesine şaşmamalıdır. O kişilere zavallı demek mümkün; galip gelen kişi Caesar iken biz zavallı olamayacağımıza göre bizden bahsetmiyorum, yıkılanlardan bahsediyorum. Belki ihtiraslı idiler belki öfkeli idiler belki de inatçı idiler. Fakat ne ölmüş Pompeius'a ne de diğer çok sayıdaki kişiye suç, delilik ya da hainlik gibi bir itham yakıştırılmamalıdır. Ey Caesar, senden kim ne zaman bu tür bir şey duydu? Senin hizmetindeki askerler sana yapılan hakarete karş1lik vermekten başka ne istedi? Senin yenilmez ordun, kendi hakkını ve senin itibarını korumaktan başka ne amaç güttü? Ne? Sen barış olsun isterken uzlaşmaya varmak istediğin yurttaşların suçlu mu yoksa masum mu olduklarını düşünüyordun? Ey Caesar, şayet ben, senin tarafından bir suçlu olarak korunmaya alındığımı düşünseydim bana 
yaptığın en büyük iyiliklerin dahi gözümde en ufak değeri olmazd. Hem sen onca kişinin gerçekten suçlu olduklarını düşündüğün halde itibarlarını korumuş olsaydın Cumhuriyete ne fayda sağlayabilirdin? Nitekim sen bunu bir 'ayrılma' olarak değerlendirdin, en başından beri bir savaş ya da düşmanca bir nefret olarak değil bilakis her iki tarafin da Cumhuriyetin esenliğini arzuladığı fakat kısmen fikirleri kısmen temayülleri bakımından ortak paydadan saptığ 1 toplumsal bir bölünme olarak düşündün. Liderlerin itibarı neredeyse birbirine denkti, onları takip edenlerinki ise herhalde denk değildi. ${ }^{39} \mathrm{O}$ sıralar durum belirsizdi çünkü her iki tarafta da takdir edilebilecek bir yan vardı. Bugün ise tanrıların desteklemiş olduğu tarafın daha iyi olduğunu kabul etmek gerekir. Hem senin ne kadar merhametli olduğunu gördükten sonra silahlananlar dışında kimsenin ölmediği bu zaferi kim takdir etmez? (Lig. 17-19)"

Cicero'nun bu şekilde savaşa ilişkin yaptığı tüm tasvirler, askeri ve siyasi açıdan Caesar dahil İç Savaşın tüm taraftarı adına niyet yönünden bir savunma niteliğindedir ve buna göre Cumhuriyet için mücadele edenler arasındaki toplumsal bölünme (civilis dissensio), nihayetinde "tanrıların desteklediğì" Caesar'ın, "silahlananlar dişında kimsenin ölmediği zafer"ine bağlanmaktadır. İç Savaşın, insanın karşısında duramayacağı tanrısal iradeye bağlanması, savaşa ilişkin hasarların kısmen görmezden gelinmesi ve bunun kabul edilebilir bir dayanak olarak sunulması, zafere ilişkin Caesar'ın sergilediği merhametin ve hoşgörünün vurgulanması deprecatio türüne uygundur.

Cicero'nun Tubero'ya bu bölümde yaptığı son itham ise doğrudan Ligarius'u da ilgilendiren Afrika meselesine ilişkindir. Ligarius'a yapılan suçlamaya ilk kez doğrudan temas eden Cicero bu noktaya şu sira ile varmıştır (Lig. 21-23): Tubero'nun babasının senato tarafından Afrika eyaletine atanması, Tubero ile babasının Afrika'ya geç varmaları, vardıklarında buranın kontrolünün çoktan Varus tarafindan ele geçirilmiş olması ve onların eyalete kabul edilmemeleri. Cicero'ya göre bu sonuncusu Ligarius aleyhindeki suçlamanın asıl dayanağıdır. Cicero bu bağlamda davanın kişisel bir husumete dayandığını ima etmiştir ve Varus'un eyalet üzerindeki yetki iddiasını vurgulayarak Tubero ile babasının eyalete kabul edilmemelerinin mesuliyetini ona atfetmiştir. Bununla beraber Cicero

39 Pompeius'un Caesar'a olan askeri üstünlüğü kastedilmektedir nitekim Pompeius İtalya'dan ayrılırken senato üyelerinin büyük bölümünün desteğini almıştır. 
Ligarius'un, Varus'un emirlerini uygulamış olmasına doğrudan işaret eden bir ifade kullanmamıştır ve "Ligarius neden Varus'un otoritesini kabul etti?" sorusunu bir kez daha göz ardı etmiştir. Cicero bunun yerine Tubero'nun babasını ısrarlı bir Pompeius yanlısı olarak Varus ile kıyaslamıştır (Lig. 2328). Bu kıyasa göre resmi açıdan Varus'a üstünlüğü bulunan baba Tubero, eyalete kabul edilmediğinde Roma'ya dönmek yerine Pompeius'a katılarak onunla (Caesar'a karşı muhalefet bakımından) durumunu eşitlemiştir. Bir kez daha varılan nokta şudur: Varus ile aynı noktada bulunan, onun gibi Afrika'y1 isteyen ve olasılıkla onu Pompeius adına isteyen baba Tubero ve oğlu affedildiklerine göre Varus'un hizmetinde bulunan Ligarius'un da affedilme hakkı bulunmaktadır.

Cicero, bu bölümdeki itham ve kıyasların tümünü, deprecatio'ya uygun olarak nihayetinde Caesar'ın bağışlayıcılığına hitap edecek şekilde tamamlamıştır:

"Ey Tubero, şimdi soruyorum, siz şahsınıza mı yoksa Cumhuriyete yapılan haksızlıkların mı peşindesiniz? Eğer Cumhuriyete ise o guruptaki istikrarınız konusunda ne yanıt vereceksiniz? Eğer şahsınıza ise Caesar'ın, kendi düşmanlarını dahi bağışlamışken sizinkilere karşı kin tutacağını düşünmek gibi bir hata yapmamaya bakın. (Lig. 29)"

Conclusio (sonsöz, Lig. 29-38) ${ }^{40}$

Konunun uygun şekilde özetlendiği ve yargıcın duygularını harekete geçirmenin amaçlandığı sonsöz bölümünde Cicero tıpkı giriş bölümünde olduğu gibi doğrudan Caesar'a hitap ederek bir kez daha savunmasının hedefini yinelemiştir:

"Her ne söylediysem tek bir noktaya temas etmesini arzu ediyorum: İnsancıllığına, merhametine ya da bağışlayıcılığına. (Lig. 29)"

Cicero bu bölümde ayrıca hayali bir mahkeme sahnesi kurgulayarak bu sahnede, deprecatio'da yeri olmayan savunma araçlarını dolaylı olarak kullanmıştır:

"Ey Caesar, itibar basamakları seni forumda tutarken ben seninle şahsen pek çok davaya katıldım. ${ }^{41}$ Şüphesiz hiç şu tarz

\footnotetext{
40 Conclusio için bk. Cic. inv. 1.98-105; Rhet. Her. 2.47-49; Quint. inst. 6.1.1-21. Ayrıca bk. Aşkit, 74-83.

41 Cicero ile Caesar'ın beraber katıldıkları bir davaya ilişkin elimizde bilgi bulunmamaktadır.
} 
bir şey duymadık: 'Bağışlayın, Sayın Yargıçlar, hata etti, yanıld1, düşünmeden yaptı, bir daha m1, asla!' Genellikle bir babaya böyle söylenir, bir yargıca ise şöyle: 'Yapmad,, aklından dahi geçirmedi, tanıklar yalancı, suç düzmece.' Sen, Caesar, de ki, ben Ligarius'un davasında yargıcım, hangi saflardaydı, diye sor. Susarım, belki yargıcın da nezdinde kıymeti olabilecek şu türden kanıtları bir araya toplamam: 'Savaştan önce legatus olarak gitti, barış zamanı orada bırakıldı, aniden savaşın ortasında kaldı, o durumda dahi muhalif olmamış bu kişi, bugün artık aklı ve yüreği ile tamamen senin hizmetindedir.' Bir yargıca böyle söylenir fakat ben bir babanın ${ }^{42}$ huzurunda şöyle derim: "Hata yaptı, kazara yapt1, pişman, senin merhametine sığınıyorum, yaptığ 1 yanlış için af diliyorum, bağışlanması için yalvarıyorum.'

(Lig. 30)"

Cicero, bu hayali sahne ile aslında neden "mahkemeler için uygun olmayan" deprecatio'ya başvurduğunu da açıklamış olur. Bu Caesar'ın merhamet etme yetkisi bulunan bir dictator olarak mahkemede üstlendiği rol ile iliş̧ilidir.

Cicero, daha sonra deperecatio tanımına uygun düşen araçları sırasıyla kullanarak konuşmasını sonlandırmıştır:

- Daha önce bağışlanmış kişilere atıfta bulunarak Caesar'dan merhamet dilemiştir (Lig. 30).

- Caesar'1 adil ve cömert biri olarak övmüştür (Lig. 31).

- Caesar'in Ligarius'u affederek kendi dostlarını da sevindirmiş olacağını söylemiştir ( Lig. 32).

- Ligarius'u desteklemek için orada bulunan, cesaretleriyle Caesar'in takdirini kazanan $\mathrm{Sabin}^{43}$ erkelerinin kederine, Ligarius'un amcasının, kuzeninin ve kardeşlerinin perişanlığına dikkat çekmiştir (Lig. 32-33).

42 İÖ 44 yılında senato tarafından Caesar'a "Pater Patriae" (Vatanın Babası) onursal unvanı verilmiştir. Cicero burada olasılıkla o dönem gündemde olan bu hususa atıfta bulunuyor olabilir. Bk. McDermott, 33. Öte yandan Gotoff'a göre bu hayali sahnede Caesar'in daha sonra alacağı unvanına değil bir komedya karakterine atıfta bulunulmaktadır. Bk. Harold Gotoff, "Cicero's Caesarian Orations", James M. May (ed.), Brill's Companion to Cicero, Ortaory and Rhetoric (Brill: 2002), 249.

43 Ligarius, Sabin soyundan gelmekte idi. Caesar, Cinna'nın kızı Cornelia ile evliliğinden ve Marius ile olan akrabalığından ötürü kendisinden nefret eden dictator Sulla'nın tehditlerinden bir dönem Sabinlerin topraklarına sığınarak kurtulabilmiştir (Plut. Caes. 1). 
- Caesar'ın, İç Savaş sırasındaki "Siz yanınızda durmayan herkesi muhalif sayarsını, ben ise bana karşı olmayan herkesi benden sayarım." sözüne atıfta bulunarak Ligarius için orada bulunan, adlarını saydığ 1 atlı sınıfından kişilerin ve ailelerinin Caesar'dan taraf olduklarını ifade etmiş ve onu bu kişilerin dostunu koruyarak sözünün eri olduğunu göstermeye teşvik etmiştir (Lig. 33).

- Ligarius ile kardeşleri arasındaki uyumdan bahsederek onların birbirlerinden fikren ayrılmalarının olanaksız olduğunu ve aslında hepsinin niyet (voluntas) yönünden Caesar'dan yana olduklarını ama birini firtınanın (tempestas) başka yöne sürüklediğini ifade etmiştir (Lig. 34).

- Ligarius bilinçli hareket etmiş olsa dahi onun durumunun her hâlükârda Caesar'ın yaşamlarını bağışladığı kişilerle eşit olacağını ifade eder (Lig. 34).

- Ligarius'in ağabeylerinden Titus Ligarius'un Caesar'a olan hizmetlerini hatırlatmıştır ( Lig. 35).

- Ligarius'u bağışlayarak onu sadece kardeşlerine, orada bulunan k1ymetli insanlara ya da sadece Caesar'ın da dostu olan kimselere değil aynı zamanda Cumhuriyete de armağan etmiş olacağını ifade etmiştir (Lig. 36).

- Caesar'1 Ligarius'u affederek halkın övgüsünü ve takdirini kazanmaya teşvik etmiştir ( Lig. 37).

- Caesar'da merhamet duyguları uyandırmak için beylik sözlerle konuşmasını tamamlamıştır:

"Hiçbir şey iyilik kadar insanca değildir, sahip olduğun sayısız erdem arasında hiçbir şey bağışlayıcılığından daha fazla hayranlık uyandıramaz ve daha fazla mutluluk veremez. Zira insanlar, diğer insanların esenliğini sağlamakla olduğu kadar başka hiçbir şekilde tanrılara bu denli yaklaşamazlar. Senin ne kaderinde sayısız insanı korumaya muktedir olmandan daha büyük bir şey ne de karakterinde onları korumayı istiyor olmandan daha güzel bir şey vardır. Dava belki daha uzun bir konuşma gerektiriyordur, senin karakterin ise şüphesiz çok daha kısasını. Bu sebeple benim ya da bir başkasının seninle konuşmasından ziyade bizzat senin 
konuşmanın daha faydalı olduğunu düşünerek konuşmamı burada sonlandıracağım. Sadece sana şunu hatırlatacağım, aramızda olmayan o kişiye esenliğini verdiğinde bunu burada mevcut olan herkese vermiş olacaksın (Lig. 37-38)."

\section{Değerlendirme}

Cicero, savunmasında müvekkilinin eylemi kasıt ile işlediğini kabul etmiş ve yargıçtan bağışlanmasını talep etmiştir. Bu bağlamda konuşmasına başlarken sözlerinin tamamının Caesar'ın bağışlayıcılığına hitap edeceğini bildirmiş ve konuşmasını buna göre düzenlemiştir.

Cicero'nun mahkemeler için uygun bulunmayan sadece nadiren ve kısmen kullanılabilen deprecatio'ya başvurması, Caesar'ın mahkemedeki rolüne ilişkindir. Caesar İç Savaşın galibi bir imperator ve bir dictator olarak Roma'daki en büyük siyasi ve askeri güçtür, bir liderdir (princeps), vatanın babasıdır (pater patriae) ve unvanlarının kendisine tanıdığı sınırsız yetkilerle davaya tek yargıç olarak başkanlık etmektedir. Caesar'ın her hâlükârda merhamet etme yetkisi bulunmaktadır. Üstelik İç Savaş sonrası Caesar, çoğunlukla siyasi sebeplerle muhaliflerini affetme yoluna gitmiştir. Cicero da sürgündeki Pompeius yanlılarının çağırılmaları için girişimlerde bulunarak bir yandan Caesar'ın merhamet politikasına hizmet etmiş bir yandan da kendi politik mevcudiyetini devam ettirmiştir. Ligarius bu anlamda halen mücadelelerini sürdürmeye devam eden Pompeius yanlılarını temsil etmektedir ve Cicero'ya göre Caesar'ın huzurunda bağışlanmayı hak eden bir sanıktır.

Ligarius deprecatio için uygun bir sanıktır çünkü geçmişte legatus olarak devlet adına hizmette bulunmuştur, yaptığı eylemi suç, nefret ya da gaddarlık ile değil görev duygusu ile yapmıştır, elinde güç varken merhametli ve yumuşak davranmıştır, yaptığı eylemden ötürü -bir sürgün olarak- yeterince ceza çekmiş görünmektedir, bağışlanması durumunda gelecekte devlete faydası olacağ 1 konusunda umut vaat etmektedir. Cicero bu doğrultuda Ligarius'un ve atalarının hizmetlerinden bahsetmiş, Ligarius'un nefretle ya da zalimlikle değil kabul edilebilir bir sebeple eylemde bulunduğunu göstermiş, daha ciddi suçlardan bağışlanan başkalarını örnek vermiş, müvekkili için mahkemede perişan vaziyette bulunan akraba ve dostlarının soyluluğuna, itibarına dikkat çekmiş, işlenen eylemi mümkün olduğunca az hasara yol açmış görünecek şekilde hafifletmiştir ve Caesar'1, sanığı bağışladığı takdirde aralarında bizzat kendi dostlarının da bulunduğu pek çok kişiyi memnun etmiş ve onu devlete 
bağışlamış olacağını belirterek buradan gelecek övgüyü kazanmaya teşvik etmiştir.

Cicero, konuşmasını türe uygun olarak düzenlemenin dışında sanığın işlediği eyleme doğrudan işaret edecek ifadelerden kaçınmıştır, sanığın mesuliyetine ilişkin soru işaretlerini göz ardı etmiştir, doğrudan savunma yapmaya yarayacak araçları kullanmamıştır ve kuramsal olarak konuşmasının her bölümünü Caesar'ın bağışlayıcılığına hitap edecek şekilde tamamlamıştır. Nihayetinde tüm bu düzenlemeler, Ligarius Savunması'nı bir deprecatio örneği olarak nitelemenin uygun olduğunu göstermektedir. 


\section{KAYNAKÇA}

\section{Antik Kaynaklar}

\section{Kisaltma ve Kullanılan Metin}

App. Pun.

Appianus, Punica = Appian. Roman History, Volume I. Tr. Brian McGing. Loeb Classical Library. Cambridge, MA: Harvard University Press, 1912.

Caes. $B C$ Caesar, Bellum Civile = Caesar. Notlar, İç Savaş Üzerine. Çev. Samet Özgüler. Doğu Batı Yayınları, 2018.

... Bell. Afr. de Bello Africo = Caesar. Alexandrian War. African War. Spanish War. Tr. A. G. Way. Loeb Classical Library. Cambridge, MA: Harvard University Press, 1955.

Cass. Dio

Dio Cassius. Roman History, Volume IV: Books 4145. Tr. Earnest Cary, Herbert B. Foster. Loeb Classical Library. Cambridge, MA: Harvard University Press, 1916.

Cic. ad. fam. Cicero, ad familiares = Cicero, Epistulae ad Familiares Vol. II. ed. Shackleton Bailey. Cambridge, 2004.

...inv. de inventione = Cicero, On Invention. The Best Kind of Orator. Topics. Tr. H. M. Hubbell. Loeb Classical Library. Cambridge, MA: Harvard University Press, 1949.

... Lig. $\quad$ Pro Ligario = Cicero: The Speeches, Pro M. Marcello, Pro Q. Ligario, Pro Rege Deiotaro. Tr. Watts, N.H. London: William Heinemann Ltd., 1931.

Plut. Caes. $\quad$ Plutarkhos, İskender-Sezar, Paralel Hayatlar. Çev. İo Çokona. İș Bankası Kültür Yayınları, İstanbul, 2015.

... Cic. Plutarkhos, Demosthenes-Cicero, Paralel Hayatlar. Çev. İo Çokona. İş Bankası Kültür Yayınları, İstanbul, 2017.

... Sull. Plutarkhos, Yaşamlar XXI, Lysandros-Sulla. Çev. A. Sarıgöllü, N. Gürsoy. Cumhuriyet Yayınları, İstanbul, 1999.

Pomp.

Pomponius, Digesta

Quint. inst.

Quintilianus, institutio oratoria $=$ Quintilian. The Orator's Education. Tr. Donald A. Russell. Loeb Classical Library. Cambridge, MA: Harvard University Press, 2002.

Rhet.Her. Cicero. Rhetorica ad Herennium. Tr. Harry Caplan. Loeb Classical Library. Cambridge, MA: Harvard University Press, 1954.

Schol. Gronov. Scholia in orationes Ciceronis Gronouiana = Erişim, 20.10.2021, https://digiliblt.uniupo.it/index.php 


\section{Modern Kaynaklar}

Aşkit, Çağatay. “Yargısal Söylev Türünde Cicero'nun Kuramları ve Uygulamalarl.” Doktora Tezi, Ankara Üniversitesi, 2006.

Bauman, Richard. "A Study of the Crimen Maiestatis Imminutae in the Roman Republic and Augustan Principate." $\mathrm{PhD}$ diss., University of the Witwatersrand, 1963.

Bringmann, Klaus. "Der Dictator Caesar als Richter? $\mathrm{Zu}$ Ciceros Reden 'Pro Ligario' und 'Pro Deiotaro'," Hermes 141 (1986): 72-88.

Craig, P. Christopher, “The Central Argument of Cicero's Speech for Ligarius”, The Classical Journal 79/3 (1984): 193-199.

Dülger, Rezzan İtişgen. "Vatana İhanet Suçunun Kökenleri Üzerine bir İnceleme", Marmara Üniversitesi Hukuk Fakültesi Hukuk Araştırmaları Dergisi 23/2 (2017): 103-142.

Fausset, W. Y. Cicero, Orationes Caesarianae, Pro Marcello, Pro Ligario, Pro Rege Deiotaro, Part II. Oxford, 1893.

Gotoff, Harold. "Cicero's Caesarian Orations", ed. James M. May, Brill's Companion to Cicero, Oratory and Rhetoric. 219-271. Brill, 2002.

Gürten, Kadir, “Roma'da Devlete Karşı İşlenen Bazı Suçlar ve Cezaları”, Ankara Barosu Dergisi 3 (2017): 54-79.

Jones, Brandtly Neal. “Caesar: Slain with Daggers but Stabbed with Words” or "Cicero as a Failure and Fraud". Chancellor's Honors Program Projects, 1998.

Kumaniecki, Kazimierz. "Der Prozess des Ligarius”, Hermes 95 (1967): 434-457.

Long, G. M. Tulli Ciceronis Orationes, Vol. 4. London, 1858.

May, James. Trials of Character: The Eloquence of Ciceronian Ethos. The University of North Carolina Press, 1988.

McDermott, William C. “In Ligarianam”, TAPA 101 (1970): 317-347.

Montague, Holly W. “Advocacy and Politics: The Paradox of Cicero's Pro Ligario”, AJPh 113/4 (1992): 559-574.

Ramos, Charles Edwars. "Politics and Rhetoric: Studies in Cicero's Caesarian Speeches.” PhD diss., University of Texas, 1994.

Rozeboom, Aaron. "The Rhetorical Implications of Clementia in Cicero's Caesarian Speeches", McNair Scholars Journal 11/1 (2007): 82-90.

Settle, James Norwood. "The Publication of Cicero's Orations." $\mathrm{PhD}$ diss., University of North Carolina, 1962.

Walser, Gerold. "Der Prozess gegen Q. Ligarius im Jahre 46 v.Chr”, Historia 8 (1959): 90-96. 